\title{
ABOUT GENESIS OF THE MOKROVOLNOVAKHA SERIES CARBONATE DEPOSITS (LOWER CARBONIFEROUS, SOUTHERN DONBAS)
}

\section{V.V. Ogar}

\author{
ПРО ГЕНЕЗИС КАРБОНАТНИХ ПОРІД МОКРОВОЛНОВАСЬКОЇ СЕРІї \\ (НИЖНІЙ КАРБОН ПІВДЕННОГО ДОНБАСУ) \\ B.B. Orap
}

Lithology, corals and genesis of the Lower Carboniferous carbonate deposits of the Mokrovolnovakha Series in the South Donets Basin are considered. The studied deposits are formed during three eustatic cycles. Composition of carbonate sediments depends on sea depth, clay content and content of magnesium, iron, and silica in sea water. Depth of sea and content of clay particles in sea water may produce either photozoic or heterozoic environment of sedimentation. At regressive phases of cycles the anoxic conditions could exist. They form favorable environment for conservation of the organic matter. Sharp changes in the lithology and fauna during Tournaisian/Viséan and Early/Late Viséan times were caused by global events. The domanic deposits of the Styla suite are considered as a result of regional volcanic event.

Key words: Lower Carboniferous, carbonate deposits, event, Donets Basin.

Розглянуто літологію, коралову фауну і походження карбонатних порід мокроволноваської серії нижнього карбону південного Донбасу. Досліджені відклади сформувались протягом трьох евстатичних циклів. На склад карбонатних осадів впливали глибина моря, вміст глинистого матеріалу, кальцію, магнію, а також кремнію і заліза в морських водах. В залежності від глибини басейну і вмісту глинистих частин існували фотозойні та гетерозойні обстановки. На регресивних фазах циклів виникали безкисневі умови, сприятливі для збереження органічної речовини. Різкі зміни літології і фауни на рубежі турнейського і візейського віків, раннього і пізнього візе пов'язані з глобальними подіями. Доманікові породи стильської світи розглядаються як результат регіональної вулканічної події.

Ключові слова: нижній карбон, карбонатні відклади, подія, Донецький басейн.

\section{ВСТУП}

Виступаючи головним джерелом видобутку флюсової сировини в Україні, карбонатна товща південного Донбасу останнім часом викликає підвищену зацікавленість дослідників у зв'язку з виявленою рудною мінералізацією, що включає поліметали, золото, фосфор, флюорит та інші компоненти [3]. У більшості випадків вона пов'язана з постмагматичними процесами. В той же час локалізація зруденіння часто обумовлена особливостями процесів седиментації та наступними діагенетичними, катагенетичними та гіпергенними перетвореннями осадів і порід. Проведена нами реконструкція генезису карбонатних порід , що базується на вивчення літології, органічних решток, узагальненні робіт попередників, покликана сприяти визначенню первинних та вторинних факторів рудоутворення в карбонатних породах регіону.

\section{РАЙОН РОБІТ}

Фактичний матеріал, покладений в основу роботи, зібрано у південній частині Донецького басейну як з природних, так і штучних відслонень (рис. 1). Найбільш повно карбонатна товща розкрита численними кар'єрами з видобутку флюсової сировини. Зокрема, дослідження охоплювали кар'єри «Центральний» і «Доломітний» Докучаєвського флюсово-доломітного комбінату, «Північний», «Південний» і «оголівський» Комсомольського рудоуправління, кар'єр «Східний» Новотроїцького рудоуправління. У природних відслоненнях нижня частина карбонатної товщі вивчалась по правому берегу р. Мокра Волноваха (балки Бузинова і Глибока, Голубина скеля), середня та верхня частини - на р. Кальміус поблизу селища 2-й Горний, на околицях селища Стила та у балці поблизу с. Кипуча Криниця.

Верхньодевонсько-нижньокам'яновугільна товща південного Донбасу уже тривалий час, починаючи 3 кінця дев'ятнадцятого століття, є об'єктом літостратиграфічних та біостратиграфічних досліджень. Їх історія викладена в роботі В.І. Полєтаєва [11]. У сучасній стратиграфічній схемі у складі карбонатної товщі виділяються новотроїцька та мокроволноваська серії. Новотроїцька серія (зона C1ta) поділяється на мафхаїнську та порфіритовську світи. У складі мокроволноваської серії виділяють вісім світ (знизу вгору): базаліївську (зона $\mathrm{C}_{1} \mathrm{tb}_{1}$ ), каракубську (зона $\mathrm{C}_{1} \mathrm{tb}_{2}$ ), волноваську (зона $\left.\mathrm{C} 1^{\mathrm{t}} \mathrm{C}\right)$, карпівську (зона $\left.\mathrm{C}_{1} \mathrm{td}\right)$, докучаєвську (зона $\mathrm{C}_{1}{ }_{1}^{\mathrm{v}}$ ), скелеватську (зони $\left.\mathrm{C}_{1} \mathrm{vb}-\mathrm{d}\right)$, стильську (зона 


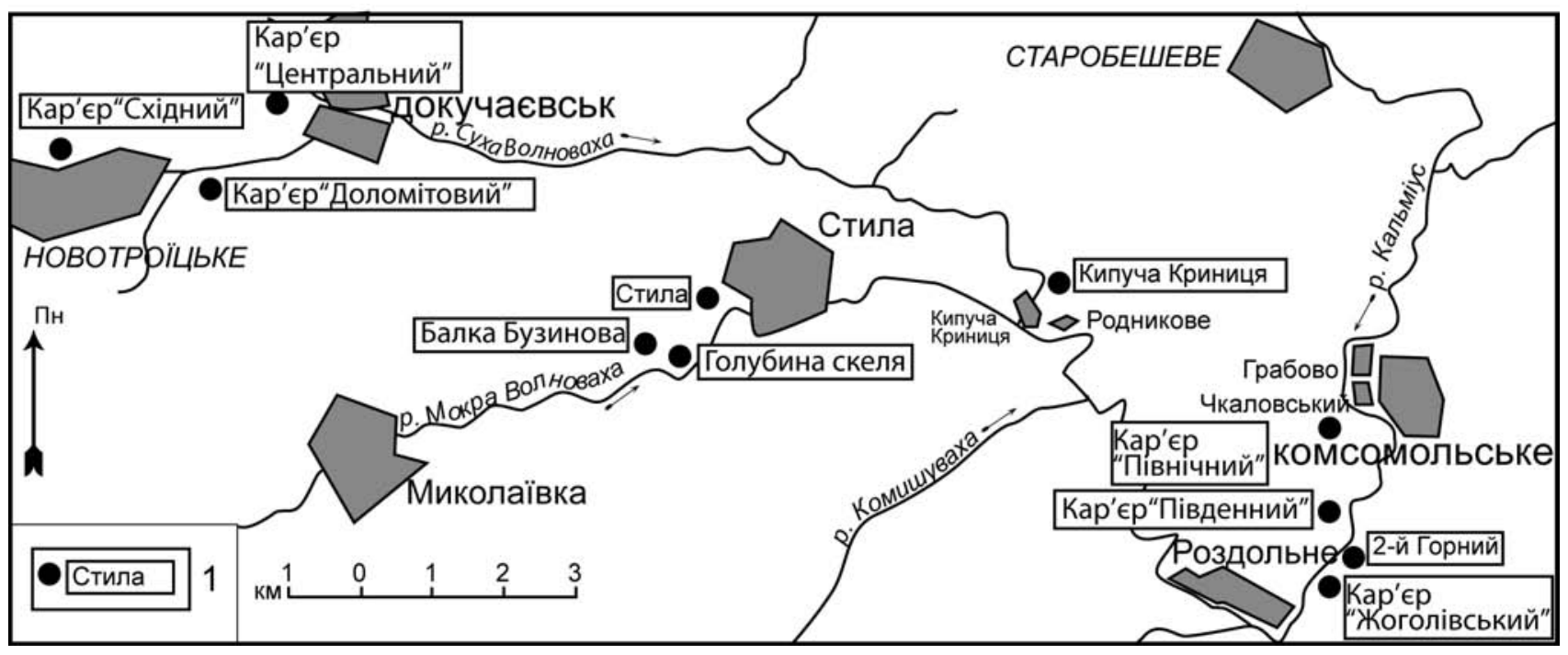

Рис.1. Оглядова схема району досліджень: 1 - вивчені розрізи та їх назви

$\mathrm{C}_{1}$ ve) та донецьку (зонаС $\mathrm{C}_{1}$ ). Ix характеристика базується на ретельно описаних стратотипах та парастратотипах [6]. За біостратиграфічними даними новотроїцька серія належить до верхнього девону, мокроволноваська - до нижнього карбону (турнейського та нижньої частини візейського ярусів). При цьому границя між турнейським і візейським ярусами проводиться по підошві скелеватської світи. Товщина карбонатних порід новотроїцької серії в розрізі по правому березі р. Мокра Волноваха досягає $80 \mathrm{м}$, мокроволноваської - $380 \mathrm{M}$.

Палеогеографічні умови формування карбонатної товщі західного сектору Великого Донбасу детально розглядались Д.Є. Айзенвергом [1]. 3 цією метою були використані польові літологічні та палеоекологічні спостереження у відкритих розрізах та за керном бурових свердловин, а також біостратиграфічні та геохімічні дослідження. Згодом ці дані були доповнені, узагальнені і систематизовані B.I. Полєтаєвим [11]. Для реконструкції давніх обстановок осадконагромадження важливе значення мали також результатами вивчення водоростей та коралів - важливих індикаторів давніх обстановок формування карбонатних порід [4, 5, 7].

\section{МЕТОДИ ТА ОБ'ЄКТ ДОСЛІДЖЕНЬ}

Проведено польові дослідження карбонатних порід верхньої частини новотроїцької та мокроволноваської серій, що супроводжувались описом літології і фауни, палеоекологічними спостереженнями. Особлива увага зверталась на вивчення фауни коралів. Відібрано зразки цих викопних решток та виконано їх лабораторне вивчення і визначення. Для пояснення походження карбонатних порід залучались дані попередніх досліджень. Вони доповнені сучасними уявленнями про мікробіальне походження значної кількості різновидів карбонатних порід, що раніше вважались хемогенними. Для пояснення генезису карбонатів застосована також концепція фотозойних та гетерозойних обстановок морського карбонатоутворення [14]. Згідно з цієї концепцією фотозойні карбонати утворюються на теплих мілководдях (середньорічна температура t $23^{\circ} \mathrm{C}$ ) з добре освітленим дном, що забезпечує розквіт бентосних фотофорних організмів. Обов'язковим компонентом сучасних фотозойних асоціацій є зелені водорості та германотипні корали з масивними скелетами. Зі збільшенням глибини басейну, зменшенням освітленості дна та зниженням температури придонних вод поступово виникає гетерозойна асоціація бентосу. Вона характеризується відсутністю зелених водоростей, замість яких можуть розвиватись багряні, розвитком агерманотипних коралів.

Вказана концепція застосована для реконструкції обстановок кам'яновугільного періоду з певними застереженнями. Серед них відзначимо дуже ймовірну відсутність германотипних коралів у карбоні. Поселення коралів (ругоз і табулят), а також гідроїдних (строматопор та хететид) виникали на мілководді при достатньому освітленні та нормальній солоності насичених киснем морських вод.

Вони рідко зустрічаються у біомікритах, доломітах та доломітизованих вапняках, але часті в біокластичних вапняках. Підвищена солоність, наявність глинистих частин та колоїдів у морських водах, 
виникнення застійних безкисневих умов - суттєво впливали на розвиток коралів та інших організмів. Зокрема, у каламутних водах глибина проникнення сонячних променів зменшувалась і гетерозойні обстановки могли виникати на мілководдях. 3 огляду на це серед вивчених коралів індикаторами фотозойних обстановок можуть бути колоніальні та значні за розмірами одиночні ругози. Індикаторами гетерозойних обстановок $€$ так звана «ціатоксонієва фауна» - асоціація дрібних одиночних ругоз без дисепиментаріуму, окремі види одиночних ругоз та деякі табуляти.

\section{РЕЗУЛЬТАТИ ДОСЛІДЖЕНЬ ТА ЇХ АНАЛІЗ}

Огляд особливостей літології карбонатних порід почнемо з верхньої частини новотроїцької серії порфіритовської світи. В розрізі по р. Мокра Волноваха вона складена вапняками сірими і зеленувато-сірими, дрібнозернистими і пелітоморфними (мадстоун), часто доломітизованими плитчастими, що у верхній частині світи (кар'єр «Східний») перешаровуються з чорними глинистими бітумінозними сланцями, в яких спостерігались включення піриту. Дрібнозернисті грудкуваті і уламкові вапняки, серед яких зустрічаються оолітові і піщанисті різновиди, охарактеризовані комплексом зелених, червоних і харових водоростей. В них знайдено також табуляти родів Roemeripora та Syringopora. У розрізі по р. Мокра Волноваха спостерігається шар (0,5 м) строкатих глин з залізистими бобовинами («сферосидерити»). За даними пошукових робіт товщина цього пласта може досягати 8 м. Подекуди він перекривається пісковиками з перевідкладеними бобовинами. У покрівлі світи на схід від дослідженого району виявлено прошарок туфопісковику [1]. Кар'єром «Доломітний» Докучаєвского ФДК у верхній частині світи розкрито прошарок мікрозернистого вапняку, складеного багряними водоростями з залишками трубчастих червів.

Базаліївська світа в дослідженому районі ймовірно трансгресивно залягає на порфіритовській. Вона досліджена в розрізі по р. Мокра Волноваха та у більшості кар'єрів. У нижній частині світи переважають сірі товстошаруваті часто доломітизовані зернисті вапняки (пакстоун-грейнстоун), що вміщують уламки одиночних ругоз, табулят Michelinia та Syringopora; присутні зелені водорості. Верхня частина світи складена переважно пелітоморфними вапняками (мадстоун) з прошарками глинистих сланців, ходами мулоїдів та полігональними тріщинами висихання (рис. 2a).
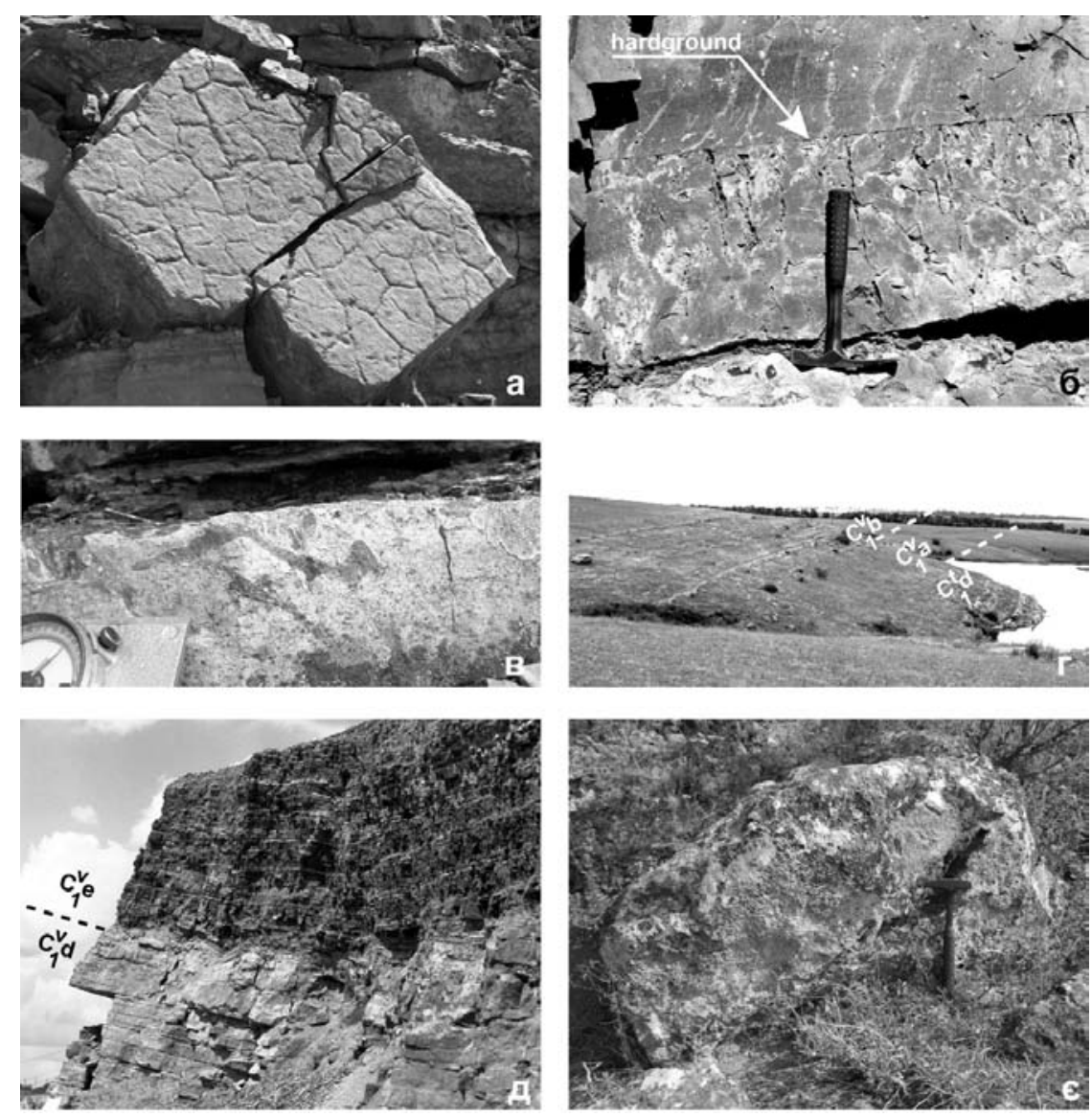

Рис. 2. Окремі відслонення та деякі деталі текстури порід мокроволноваської серії:

а - полігональні тріщини висихання на поверхні нашарування вапняків базаліїївської світи, кар'єр «Східний»; б - вертикальні ходи мулоїдів Skolithos, що починається від поверхні hardground, у вапняках карпівської світи, кар'єр «Північний»; в - ходи Zoophycos у вапняках верхньої частини базаліївської світи, Голубина скеля; г - загальний вигляд відслонення Голубина скеля з виходами карпівської, докучаєвської та скелеватської світ; д контакт (з ознаками палеокарсту) вапняків карпівської світи і кременистих мергелів з прошарками бентонітоподібних глин стильської світи, кар'єр «Центральний»; $€-$ біогермні коралові вапняки донецької світи, околиці с. Стила 
Каракубська світа вивчалась у розрізі по р. Мокра Волноваха та в кар'єрі «Доломітний». Вона складена світло-сірими тонкозернистими часто плямистодоломітизованими вапняками з тонкими прошарками чорних глинистих сланців. В нижній частині розміщуються витримані прошарки вапняків, переповнені брахіоподами («медіусові шари»). У верхній частині переважають пелітоморфні вапняки (мадстоун). Остання відділена від нижньої прошарком зеленувато-сірих глинистих сланців (близько 50 см), якому в кар'єрах часто відповідає прошарок крупнозернистого пісковику (1,5-2 м). Макрофауна в цих породах не знайдена. Серед водоростей переважають синьо-зелені.

Волноваська світа складена сірими уламковими біоклатичними вапняками (пакстоун-грейнстоун), що вміщують виключно зелені водорості та багатий комплекс макрофауни. Серед коралів часті табуляти Syringopora, Roemeripora та крупні одиночні ругози Keyserlingophyllum, Cyathoclisia i Sychnoelasma.

Карпівська світа відслонена на р. Мокра Волноваха (Голубина скеля), розкрита кар'єром «Північний» та ін. Вона поділяється на дві підсвіти. Нижня - складена сірими пелітоморфними (мадстоун) масивними вапняками, які майже не вміщують макрофауністичних решток. У кар'єрі «Північний» спостерігались вертикальні ходи мулоїдів типу Skolithos та поверхні hardgraund (рис. 2б). У згусткових різновидах вапняків О.І. Берченко виявлено збіднений комплекс водоростей і форамініфер.

На відміну від нижньої, верхня підсвіта складена темно-сірими до чорних дрібнозернистими глинистими та бітумінозними токоплитчастими вапняками. Серед них переважають уламкові форамініферово-детритусові пакстоуни і згусткові. Вапняки вміщують багатий комплекс зелених водоростей і форамініфер. Часто зустрічаються також дрібні одиночні ругози Amplexus, Conilophyllum, табуляти Syringopora та Aulopora, брахіоподи, двостулкові молюски, моховатки. Дуже часті також сліди Zoophycos (рис. 2в). Д.Є. Айзенверг вказував на сліди вивітрювання, що спостерігались у покрівлі цих відкладів.

Докучаєвська світа складена чорними глинистими бітумінозними сланцями, що перешаровуються з темно-сірими дрібнозернистими бітумінозними вапняками. Породи, що складають світу, легко руйнуються і майже не відслонюються (рис. 2г). У стратотипі світи (Голубина скеля) вони розкриті канавою. Проте у більшості кар'єрів світа добре розкрита і доступна для детального вивчення. Встановлено, що на захід від району досліджень вона з розмивом залягає на більш давніх утвореннях [2, с. 19], а згодом повністю виклинюється.

Незважаючи на незначну товщину (6 м), бітумінозність та піритизацію, світа багато охарактеризована фауною - брахіоподами, коралами, форамініферами, двостулковими молюсками, моховатками. Серед брахіопод найбільш типовою є Levitusia humerosa (Sow), серед коралів - табуляти Syringopora, одиночні ругози Calmiussiphyllum (масово), зрідка бездисипиментні Fasciculophyllum. Спостерігались ходи мулоїдів Taonurus. Визначено також багато видів зелених водоростей.

Скелеватська світа добре відслонюється по р. Мокра Волноваха (від Голубиної скелі до гирла балки Глибока) та на повну товщину розкрита кар'єром «Центральний». Поділяється на дві частини (підсвіти). Нижня складена одноманітними сірими форамініферовими або форамініферово-водоростевими пакстоунами і грейнстоунами товстоплитчастими та масивними, верхня - виділяється за появою жовен і лінз чорних кременів. Породи вміщують багату та різноманітну макрофауну: брахіоподи, остракоди, колоніальні гіллясті та масивні ругози, табуляти. Особливо примітна поява значної кількості колоніальних ругоз, що належать до родів Siphonodendron, Lonsdaleia, Lithostrotion, Diphyphyllum. Виявлено також багатий комплекс зелених водоростей.

Стильська світа в природних відслоненнях зустрічається фрагментарно. Стратотип її знаходиться на околицях селища Стила, де доступна для вивчення лише її нижня частина. На повну товщину розкрита в кар'єрі «Центральний» (рис. 2д). На нашу думку немає прямих доказів незгідного залягання стильської світи на скелеватській. Породи, що складають світу, легко вивітрювались і часто занурювались у палеокарстові нерівності і глибокі провалля. Це може створювати ілюзію незгідного залягання. Насправді непрямим доказом його існування є лише різка зміна порід та виявлений Д.Є. Айзенвергом в св. 1025 прошарок середньозернистого кварцового пісковику з галькою кварцу і кременів, локалізований у нижній частині світи. Стильська світа складена нетиповими для мокроволноваської серії темно-сірими і чорними тонкоплитчастими кременистими мергелями, збагаченими органічною речовиною сапропелевого походження. На незначній висоті від підошви фіксується декілька малопотужних світло-коричневих прошарків бентонітоподібних глин та рудний пласт (30 см), до скла- 
ду якого у значних кількостях входять оксиди заліза та марганцю. Світа поділяється на дві частини (підсвіти). У нижній частині макрофауна майже не зустрічається. У тонкозернистих кременистих мергелях зафіксована значна кількість залишків організмів з кременистим скелетом - радіолярій та спікул губок. Натомість, в органогенних вапняках верхньої частини світи знайдена багата та різноманітна фауна: форамініфери, брахіоподи, двостулкові молюски, гастроподи, амоноідеї, трилобіти, кріноідеї, моховатки, одиночні ругози Zaphrentites та два види табулят - Cladochonus, Sutherlandia. У корах вивітрювання балки Бузинової, що розміщуються тут серед турнейських вапняків, було знайдено породи з ходами точильників та залишками флори. Водорості майже не зустрічаються. В покрівлі світи фіксується стратиграфічна перерва, проявлена у вигляді бокситоносної кори вивітрювання [3].

Донецька світа детально вивчена в природних відслоненнях - у стратотипі (селище 2-й Горний), поблизу с. Кипуча Криниця та на околиці селеща Стила. Ї̈̈ нижня частина складена світло-сірими біокластичними вапняками (пакстоун и грейнстоун) з уламками масивних колоній ругоз роду Lithostrotion, середня - біоморфними кораловими вапняками (баффлстоун), утвореними крупними колоніями та нашаруванням гіллястих колоній Siphonodendron junceum (Fleming), що формують біостроми (рис. 2.6). В середній частині з'являються лінзи і прошарки чорних кременів, кількість яких збільшується у верхній. Часто зустрічаються гігінтопродуктиди, які утворюють брахіоподові банки, хететиди та крупні одиночні ругози родів Palaeosmilia, Dibunophyllum. У породах виявлені різноманітні водорості, серед яких різко переважають зелені та багряні. Багато представлені і інші групи фауни - форамініфери, двостулкові молюски, гастроподи та ін. Донецька світа завершує карбонатний розріз мокроволноваської серії. Від наступної межівської світи вона без явної незгідності відділена прошарком світлосірих глинистих сланців. 3 них починається потужна товща ритмічного перешарування аргілітів, алевролітів, пісковиків і вапняків.

\section{РЕКОНСТРУКЦІЯ УМОВ ФОРМУВАННЯ КАРБОНАТНИХ ПОРІД}

Проведені дослідження вапнякової товщі південного Донбасу підтверджують давно зроблений висновок про утворення нижньокам'яновугільної карбонатної товщі в умовах теплого мілководно-морського басейну. Розпочавшись наприкінці девону, формування карбонатної товщі продовжувалось протягом турнейського та першої половини візейського часів. Воно є результатом декількох трансгресивно-регресивних циклів, виділених Д.Є. Айзенвергом та уточнених В.І. Полєтаєвим - бузинівського, оленівського і єфремівського (рис 3). Трансгресивні фази цих циклів супроводжувались нагромадженням карбонатних осадів, встановленням фотозойних обстановок, в яких утворювались органогенні карбонатні осади, а при збільшенні солей кальцію і магнію - біохемогенні (мікробіальні) та хемогенні вапняки і доломіти. На регресивних фазах циклів періодично виникали (можливо на фоні відносної ізоляції басейнів і опріснення вод) застійні безкисневі умови. Такі періоди супроводжувались суттєвим збільшенням кількості глинистого матеріалу в басейнах. Внаслідок цього виникали гетерозойні обстановки, сприятливі для концентрації та збереження від окиснення органічної речовини. Ніяких переконливих ознак глибоководного осадконагромадження протягом формування карбонатної товщі не виявлено.

Нагромадження порід порфіритовської світи відбувалось у мілководно-морських нестабільних умовах. В цілому фотозойні обстановки, в яких утворювались переважно мікробіальні вапняки, ускладнювались ізоляцією мілководь, зростанням солоності та викликали появу хемогенних осадів. Зрідка встановлювались нормально-морські умови, індикаторами яких є колонії табулят. У пізньопорфіритовський час виникали гетерозойні застійні умови з обмеженим доступом кисню, що впливало на збільшення вмісту органічної речовини. Привнесення у морський басейн значної кількості заліза (ймовірно на фоні високого вмісту розчиненого у воді вуглекислого газу) призводило до утворення сферосидеритів, порушуючи або і повністю зупиняючи процес карбонатної седиментації.

Породи, що складають базаліївську світу також формувались переважно у фотозойних умовах при поступовому зменшенні глибини басейну, його частковій ізоляції, збільшенні солоності та періодичному осушуванні. Це підтверджується наявністю біокластичних вапняків з уламками ругоз та колоніями табулят у нижній частині світи, що змінюються пелітоморфними вапняками з полігональними тріщинами висихання у верхній.

У каракубський час продовжували існувати дуже мілководні з підвищеною солоністю морські басейни. В них складались умови, несприятливі для існування бентосу та інших організмів. Тому серед карбонатних осадів у цей час переважали мікобіальні вапняки. 


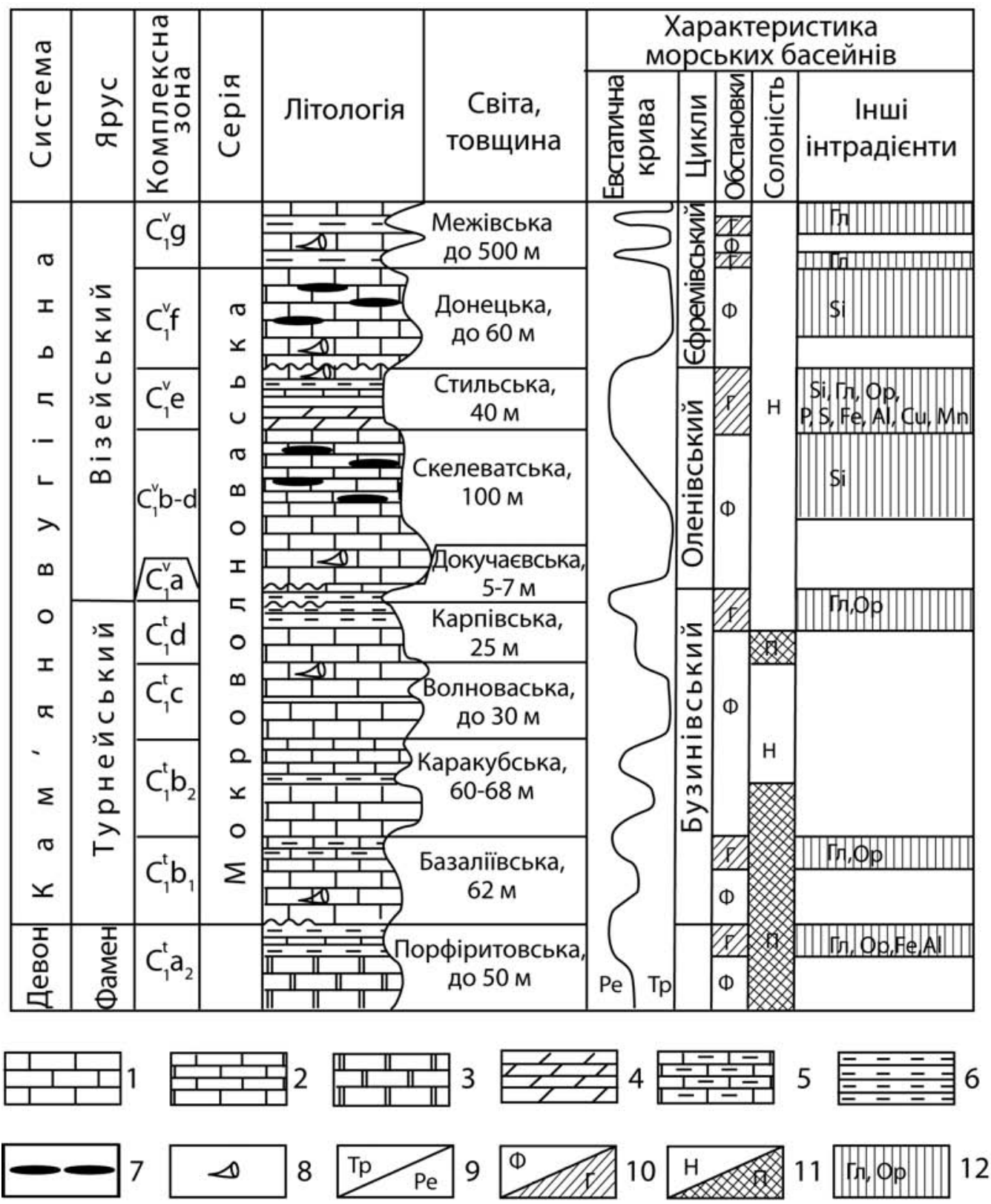

Рис. 3. Схема літології, стратиграфії та умов формування мокроволноваської серії: 1 - вапняки зернисті (біогенні); 2 - вапняки мікритові (біохемогенні); 3 - доломіти; 4 - вапняки глинисті; 5 - кременисті мергелі; 6 - аргіліти (сланці); 7 - кремені; 8 - корали; 9 - Тр - трансгресії, Ре - регресії; 10 - обстановки осадконагромадження: Ф - фотозойні; Г - гетерозойні; 11 - солоність: Н - нормальна; П - підвищена; 12 - інші інгредієнти морських вод: Гл - глинистий матеріал; Ор - органічна речовина; $\mathrm{Si}, \mathrm{Fe}, \mathrm{Al}, \mathrm{Cu}, \mathrm{Mn}, \mathrm{S}, \mathrm{P}$ - підвищені концентрації хімічних елементів

Оптимальні умови для розвитку планктонних організмів і бентосу існували під час формування наступної волноваської світи. Різноманітні корали, зелені водорості, брахіоподи, моховатки - вказують на фотозойні умови мілководного шельфу. Вапняки волноваської світи фіксують максимум бузинівської трансгресії.

Проте вже на початку карпівського часу знову відновились дуже мілководні умови з підвищеною солоністю морських вод утворенням мікробіальних вапняків. У пізньокарпівський час у морських водах періодично збільшувалась кількість глинистого матеріалу та органічної речовини. Про дуже мілководні умови свідчать ходи мулоїдів, поверхні hardground. Так, за даними Р.Ф. Геккера [8], сліди життєдіяльності Zoophycos характеризують прибережне мілководдя. 
Породи докучаєвської світи суттєво відрізняються від інших значною глинистістю та підвищеним вмістом органічної речовини. Аналіз фауни, у тому числі коралів, показує, що ці утворення формувались у фотозойних умовах (вапняки з зеленими водоростями), що часто змінювались гетерозойними (глинисті сланці з включеннями піриту, одиночними ругозами і колоніями табулят). При цьому гетерозойні умови виникали не стільки за рахунок збільшення глибини басейну, скільки у зв'язку з привнесенням великої кількості глинистого матеріалу і зменшення глибини проникнення світла.

Під час утворення скелеватської світи склалися сприятливі умови для існування різноманітних організмів та виникнення біокластичних вапняків. Багата фауна, в тому числі корали та зелені водорості, свідчать по існування стабільних фотозойних мілководношельфових умов, які дещо порушувались зі збільшенням концентрації кремнію у пізньоскелеватський час. Скелеватська світа фіксує максимум оленівської трансгресії.

У морських водах стильського часу різко зростає вміст кремнію, утворюються відновлювальні безкисневі умови, що сприяли накопиченню та збереженню органічної речовини і утворенню доманікових порід. На нашу думку немає достатніх підстав вважати, що стильський басейн був глибоководним. С.В. Максимовою [9] достатньо переконливо показано, що доманікові породи могли утворюватись у порівняно неглибоких морських басейнах, а специфічний склад фауністичних решток (радіолярії, спікули губок, що складені оксидом кремнію) пояснюється високим вмістом кремнію у морських водах. Останнє могло обумовлюватись спалахом вулканізму на суміжних територіях. У нашому випадку доказом такої вулканічної діяльності можуть виступати прошарки бентонітоподібних глин у нижній частині стильської світи. Що ж стосується гіпсових та залізо-марганцевих прошарків, то вони, очевидно, утворились в результаті накладених постседиментаційних гідрогенних процесів. У пізньостильський час, коли вміст кремнію у морських водах зменшився, з'явилась різноманітна, хоча і специфічна фауна гетерозойних обстановок (зелені водорості практично відсутні).

Формуванню донецької світи передував перерив в осадконагромадженні. В цей час породи перебували в зоні гіпергенезу. Відбувались процеси хімічного вивітрювання і утворення кори вивітрювання. Наступна пізньовізейська трансгресія призвела до виникнення фотозойних обстановок та оптимальних умов для розвитку різноманітних живих організмів. Спостерігається розквіт коралів, які часто складають коралові біостроми та біогерми. У другій половині донецького часу у морських водах знову дещо збільшився вміст кремнію, свідченням чого є значна кількість кременистих виділень у верхній частині світи. В цілому ж донецькою світою завершився процес формування карбонатної серії Південного Донбасу в умовах мілководношельфових морів. Починаючи з межівського часу, виникає паралічний басейн з частою зміною обстановок осадконагромадження.

\section{ВИСНОВКИ}

Нижньокам'яновугільна карбонатна товща $€$ результатом декількох трансгресивно-регресивних циклів. Пов'язане з евстатичними коливаннями чергування фотозойних та гетерозойних обстановок відносно мілководного шельфу, порушувалось рядом головним чином місцевих факторів. Серед них:

- значні обміління басейну, які призводили до збільшення концентрації солей у морських водах і виникнення біохемогенних та хемогенних вапняків і доломітів;

- привнесення заліза та утворення сферосидеритів;

- збільшення концентрації кремнію у воді та поява кременисто-глинистих відкладів і кременів;

- збільшення кількості глинистого матеріалу та утворення глинистих вапняків і глин;

- поява застійних можливо дещо опріснених басейнів з безкисневими умовами, що сприяли збереженню органічної речовини, утворенню бітумінозних порід і доманікових фацій;

- перериви в осадконагромадженні, що призводили до відкладення теригенних порід та формуванню кори вивітрювання.

Поряд з місцевими факторами, в породах мокроволновалької серії приховуються сліди значних регіональних та глобальних подій, які кардинально впливали на розвиток фауни і флори, зокрема коралів. За сучасного стану вивченості літології і фауни нижнього карбону в Європі та у світі в цілому деякі з них достатньо чітко виявляються.

Так, встановлена близька до синхронної поява доманікових порід, що, крім Південного Донбасу, фіксується також в Дніпровсько-Донецькій западині, Львівському палеозойському прогині, Придобруджинському прогині [10]. Ймовірно, що у цьому випадку ми маємо справу з вулканічною подією регіонального масштабу. 
Органогенні вапняки донецької світи, що з перервою перекривають стильську, характеризуються появою різноманітних коралів, що формують коралові біогерми і біостроми. Порівняльний аналіз показує, що подібні органогенні споруди з'являються на близьких стратиграфічних рівнях у Львівському прогині [12], а також у Бельгії, Великобританії, Південній Франції, Китаї, Японії $[13,16]$, що свідчить про виникнення в цей час сприятливих умов для інтенсивного коралового біогермоутворення у всій екваторіальній зоні.

Важливий рубіж встановлюється також поблизу сучасної турнейсько-візейської границі. У Донбасі верхи турнейського ярусу складені бітумінозними вапняками і сланцями докучаєвської світи із специфічною, часто ендемічною, кораловою фауною. Вище вони різко змінюються біокластичними вапняками склеватської світи з багатою фауною нижнього візе, яка має значне географічне поширення. За літологічними ознаками та зміною фауни цей рубіж простежується також у Бельгії та Південній Франції, Великобританії, Південній Польщі, Китаї, Японії, Австралії і пояснюється глобальною евстатичною подією [15].

Проведені дослідження вказують на те, що підвищені вмісти фосфору, золота і ряду інших металів та радіоактивних елементів у стильській світі пов'язані з формуванням доманікових порід. Первинноосадовий характер мають також залізорудні утворення порфіритовської світи, збагачені органічною речовиною породи з верхньої частини цієї світи, а також бітумінозні утворення докучаєвської та стильської світ. Точки мінералізації у вивітрених породах верхньої частини стильської світи, залізомарганцевий пласт, гіпсові прошарки як і прояви карсту мають вторинний накладений характер. Вони обумовлені перебуванням порід в зоні гіпергенезу а також циркуляцією термальних підземних вод, яка супроводжувалась мобілізацією та перерозподілом рудних компонентів в карбонатній товщі.

1. Айзенверг Д.Е. Стратиграфия и палеогеография нижнего карбона западного сектора Большого Донбасса. - К.: Издательство АН УССР, 1958. - 272 с.

2. Айзенверг Д.Е., Бражникова Н.Е., Новик Е.О., Ротай А.П., Шульга П.Л. Стратиграфия каменноугольных отложений Донецкого басейна. - К.: Издательство АН УССР, 1963. - 182 с.

3. Артеменко В.М., Артеменко О.В., Пономарьов В.Є., Черніцина О.М. Крандаліт - новий тип фосфатної мінеральної сировини в Україні // Мінеральні ресурси України. - 2000. - №2. - С. 31-34.

4. Берченко О.И. О фациальной приуроченности известковых водорослей турнейских отложений Донбасса // Геологический журнал. - 1976. - Т. 36. - Вып. 5. - С. 96-104.

5. Берченко О.І., Сухов О.А. Фаціальна приуроченість вапнистих водоростей у візейських відкладах Донбасу // Проблеми палеонтології та біостратиграфії протерозою та фанерозою України. - К., 2006. - С. 66-70. (Зб. наук. праць ІГН НАНУ).

6. Вдовенко М.В., Берченко О.И. Полетаев В.И. Стратотипы региональных стратиграфических подразделений нижнего карбона Доно-Днепровского прогиба (турнейский и визейский ярусы). - К., 1992. - 52 с. - (Препринт 92-4 Института геологических наук АН Украины).

7. Василюк Н.П. Нижнекаменноугольные кораллы Донецкого бассейна. - К.:Издательство АН УССР, 1960. - $179 \mathrm{c}$.

8. Геккер Р.Ф. Следы беспозвоночных и стигмарии в морских отложениях нижнего карбона Московской синеклизы. М.: Наука, 1980. - 89 с.
9. Максимова С.В. Эколого-фациальные особенности и условия образования доманика. - М.: Наука, 1970 - 86 с.

10. Мачуліна С.О. Особливості осадконагромадження візейських доманікитів Дніпровсько-Донецької западини // Нафтова і газова промисловість. - 1993. № 2. - С. 10-15.

11. Полетаев В.И. Литостратиграфическое расчленение известняковой толи нижнего карбона Донецкого басейна. - К.: 1981. - 50 с. - (Препринт 81-34 Института геологических наук АН УССР).

12. Шульга В.Ф., Огарь В.В. Первые находки коралловых построек в раннем карбоне Львовского палеозойского прогиба // Доповіді НАНУ. - 2007. - № 9. - С. 101-109.

13. Aretz M., Webb G.E. Western European and eastern Australian Mississippian shallow-water reefs: a comparison // Preceedings of the XVth International Congress on Carboniferous and Permian Stratigraphy. - Amsterdam: 2007. - P. 433-442.

14. James N.P. The cool-water carbonate depositional realm // Society of Economic Paleontologists and Mineralogists Special Publication. - 1997. - No. 56. - P. 1-20.

15. Poty E. The "Avins event": a remarkable worldwide spread of corals at the end of the Tournaisian (Lower Carboniferous ) // Proceedings of the 9th International Symposium on Fossil Cnidaria and Porifera. - Wien: 2007. P. 231-249.

16. Somerville I.D. Rugose coral faunas from Upper Viséan (Asbian-Brigantian) buildups and agecent platform limestones, Kingscourt, Ireland // Bol. R. Soc. Esp. Hist. Nat. (Sec. Geol.). - 1997. - 92. - (1-4). - P. 35-47. 